\title{
Effect of aerobic training on the host systemic milieu in patients with solid tumours: an exploratory correlative study
}

\author{
O K Glass ${ }^{1}$, B A Inman ${ }^{1}$, G Broadwater ${ }^{1}$, K S Courneya ${ }^{2}$, J R Mackey ${ }^{2}$, S Goruk ${ }^{2}$, E R Nelson ${ }^{1}$, J Jasper ${ }^{1}$, \\ C J Field ${ }^{2}$, J R Bain ${ }^{1}$, M Muehlbauer ${ }^{1}$, R D Stevens ${ }^{1}$, M D Hirschey ${ }^{1}$ and L W Jones ${ }^{\star}, 3$ \\ ${ }^{1}$ Duke University Medical Center, Durham, NC, USA; ${ }^{2}$ University of Alberta, Edmonton, Alberta, Canada and ${ }^{3}$ Department \\ of Medicine, Memorial Sloan Kettering Cancer Center, 300 East 66th Street, New York, NY 10065, USA
}

Background: Few studies have investigated the effects of exercise on modulation of host factors in cancer patients. We investigated the efficacy of chronic aerobic training on multiple host-related effector pathways in patients with solid tumours.

\begin{abstract}
Patients and Methods: Paired peripheral blood samples were obtained from 44 patients with solid tumours receiving cytotoxic therapy and synthetic erythropoietin (usual care; $n=21$ ) or usual care plus supervised aerobic training $(n=23)$ for 12 weeks. Samples were characterised for changes in immune, cytokine and angiogenic factors, and metabolic intermediates. Aerobic training consisted of three supervised cycle ergometry sessions per week at $60 \%$ to $100 \%$ of peak oxygen consumption $\left(\mathrm{VO}_{2 \text { peak }}\right)$, 30-45 min per session, for 12 weeks following a nonlinear prescription.
\end{abstract}

Results: The between-group delta change in cardiopulmonary function was $+4.1 \mathrm{ml} \mathrm{kg}^{-1} \mathrm{~min}^{-1}$, favouring aerobic training $(P<0.05)$. Significant pre-post between-group differences for five cytokine and angiogenic factors $(H G F, I L-4$, macrophage inflammatory protein-1 $\beta$ (MIP-1 $\beta$ ), vascular endothelial growth factor (VEGF), and TNF- $\alpha$ ) also favour the aerobic training group $\left(P^{\prime} s<0.05\right)$. These reductions occurred in conjunction with nonsignificant group differences for T lymphocytes $\mathrm{CD} 4^{+}, \mathrm{CD} 8^{+}$, and $\mathrm{CD} 8{ }^{+} / \mathrm{CD} 45 \mathrm{RA}(P<0.10)$. For these factors, circulating concentrations generally increased from baseline to week 12 in the aerobic training group compared with decreases or no change in the usual care group. No significant changes in any metabolic intermediates were observed.

Conclusions: Aerobic training alters host availability of select immune-inflammatory effectors in patients with solid tumours; larger confirmatory studies in more homogenous samples are warranted.

The past decade has witnessed a significant increase into investigation of structured exercise training across the entire cancer survivorship continuum (i.e., diagnosis to palliation) in a broad range of solid and haematological malignancies (Jones and Alfano, 2013). Data from randomised trials demonstrate that exercise training (i.e., aerobic, resistance, or combination modality training) is a well-tolerated adjunct strategy associated with favourable improvements in a number of symptom control outcomes, including improvements in fatigue, physical functioning, and various aspects of quality of life, both during and following the completion of primary therapy (Speck et al, 2010; Jones et al, 2011).

An initially unanticipated but emerging additional potential benefit of exercise training is as a novel form of anticancer (adjuvant) therapy (Betof et al, 2013). Intriguingly, preliminary data indicate, in general, an inverse independent relationship between higher levels of physical activity (an overarching term that includes exercise; exercise defined as purposeful physical activity with the goal of health improvements and cardiorespiratory fitness) and cancer-specific outcomes (as well as

*Correspondence: Dr LW Jones; E-mail: jones13@mskcc.org

Data presented in part at the 9th AACR-JCA Joint Conference: Breakthroughs in Translational Research and the 2013 AACR Annual Meeting.

Received 27 October 2014; revised 1 December 2014; accepted 17 December 2014; published online 13 January 2015

(c) 2015 Cancer Research UK. All rights reserved 0007-0920/15 
overall mortality) in patients with breast, prostate, or colorectal cancer (Ballard-Barbash et al, 2012; Betof et al, 2013). Confirmatory phase II/III data are currently not available, although at least two large phase III trials are currently in progress with cancer-specific end points (i.e., progression-free survival) as the primary end point. Nevertheless, as with the development of all novel anticancer therapies, whether pharmacologic or nonpharmacologic, a critical pre-requisite to optimise the safety and potential efficacy is elucidation of the cancer cell intrinsic as well as the systemic/microenvironmental mechanisms of action. Such work will inform the selection of patients most likely to benefit from exercise treatment in subsequent trials, facilitating the shift towards personalised medicine (Betof et al, 2013).

The current working model postulates that exercise may inhibit tumour progression and metastasis via modulation of the hosttumour interaction (Betof et al, 2013). Tumour progression is regulated by complex, multifaceted interactions between the systemic milieu (host), tumour microenvironment, and cancer cells (Straussman et al, 2012). The tumour microenvironment, whether in the primary or distant ectopic sites, is directly influenced and responsive to the plethora of circulating growth factors, cytokines and angiogenic factors, hormones, and other numerous cell types that comprise the systemic host milieu (McAllister et al, 2008; McAllister and Weinberg, 2010). Indeed, higher circulating (systemic) levels of certain inflammatory cytokine and angiogenic factors (e.g., hepatocyte growth factor (HGF), tumour necrosis factor (TNF), and interleukin-6 (IL-6); Sheen-Chen et al, 1997; Zhang and Adachi, 1999; Sheen-Chen et al, 2005) as well as metabolic growth hormones (e.g., insulin, glucose, and leptin; Goodwin et al, 2012) are associated with higher risk of recurrence and cancer-specific mortality in a number of solid malignancies (Hursting and Berger, 2010). These data therefore support the overarching view that aberrant production/ bioavailability of multiple growth factors in the circulation act in concert to promote a tumourigenic systemic milieu that, in an evolutionary-like manner, drives alterations as well as cooperating events in malignant and nonmalignant cells to drive tumour progression (Barcellos-Hoff et al, 2013).

In noncancer populations, chronic aerobic (endurance) training via activation of a highly complex, dynamic, and orchestrated gene expression response is a potent modulator of multiple systemic factors including metabolic, immune-inflammatory, and reactive oxygen species pathways (Joyner and Green, 2009). These alterations act in concert to dramatically shift the global systemic milieu that, in turn, is postulated to mediate the remarkable pleiotropic benefits of regular exercise (Kodama et al, 2009; Lee et al, 2012). As a logical extension, aerobic training may also effectively counteract or nullify the strong evolutionary selection imposed by a tumourigenic systemic milieu to inhibit tumour progression. To date, few studies have investigated the effects of aerobic training treatment on modulation of host factors (Betof et al, 2013). The few available studies focus on a limited number of growth factors within an isolated pathway, principally the glucoseinsulin axis, with no clear conclusions at present (Betof et al, 2013). As the host-tumour interaction is modulated by numerous hostrelated factors working in concert across multiple pathways, it is critical to investigate exercise treatment effects on these pathways simultaneously.

Against this background, here we extend prior work by investigating the effects of chronic aerobic training on modulation of multiple host-related effector pathways representing metabolic and immune-inflammatory mediators in patients with solid tumours undergoing cytotoxic and supportive care (i.e., synthetic erythropoietin) therapies. We hypothesised that aerobic training would cause favourable alterations in metabolic and immuneinflammatory pathways compared with usual care.

\section{MATERIALS AND METHODS}

Clinical trial patients and procedures. Full details regarding the parent clinical trial have been previously published (Courneya et al, 2008). In brief, major eligibility criteria were: (1) histologically confirmed diagnosis of a solid malignancy, (2) haemoglobin $(\mathrm{Hb})$ level between 80 and $100 \mathrm{gl}^{-1}$, and (3) expected survival of $\geq 3$ months. Baseline level of exercise behaviour was not an eligibility criterion. Patients were randomised with an allocation ratio of $1: 1$ to: (1) synthetic erythropoietin (i.e., darbopoetin- $\alpha$ ) usual care $(n=29)$ or (2) synthetic erythropoietin with concurrent aerobic training $(n=26)$, for 12 weeks. Study-related assessments were standardised such that the timing and exposure to synthetic erythropoietin was identical in both groups. The final synthetic erythropoietin infusion was provided at least 7 days before the postintervention fasted blood samples were acquired. Institutional review boards approved the trial and informed consent was obtained from all participants before initiation of any study-related procedures.

Synthetic erythropoietin treatment. All participants $(n=55)$ were evaluated for synthetic erythropoietin treatment at a dose of $4.5 \mu \mathrm{g} \mathrm{kg}^{-1}$ on weeks $1,2,3,4,5,8$, and 11 . Synthetic erythropoietin was withheld if the patient's Hb concentration was $\geq 140 \mathrm{gl}^{-1}$ for men or $\geq 130 \mathrm{gl}^{-1}$ for women. Treatment was reinstated at $50 \%$ of the previous dose when the $\mathrm{Hb}$ level returned to $<120 \mathrm{gl}^{-1}$. Participants were instructed to maintain their usual exercise levels and not to initiate a structured exercise training programme.

Aerobic training treatment. The aerobic training prescription was developed using a nonlinear approach adhering to the principles of training, permitting the design of individualised prescriptions, with the aim of increasing peak oxygen consumption $\left(\mathrm{VO}_{2 \text { peak }}\right)$. A nonlinear approach sequences aerobic training sessions such that physiological stress is continually altered in terms of intensity and duration in conjunction with appropriate rest and recovery to optimise adaptation (Figure 1A). Aerobic training consisted of three supervised (stationary) cycle ergometry sessions per week, 2045 min per session, at $55 \%$ to $100 \%$ of $\mathrm{VO}_{2 \text { peak }}$ for 12 weeks. Aerobic training intensity was based on the workload (W) corresponding to a specific percent of $\mathrm{VO}_{2 \text { peak }}$ (e.g., 55\%, 65\%) elicited during the prerandomisation or mid-point cardiopulmonary exercise test. $\mathrm{VO}_{2 \text { peak }}$ was reassessed at week 6 (mid-point) to represcribe aerobic training. During all supervised sessions, training intensity and safety was monitored continuously via heart rate, and blood pressure was monitored at the beginning, middle, and end of each session. Adherence was calculated as the number of training sessions attended divided by the total number of planned sessions (i.e., 36). Aerobic training participants received the same dose and schedule of synthetic erythropoietin as the usual care group.

Blood collection. Participants $(n=44)$ were instructed not to perform any exercise for at least $48 \mathrm{~h}$ before blood collection. Blood was collected between 0700 and $1000 \mathrm{~h}$, after a 12-h water-only fast. Blood collection was standardised across all patients in terms of day of collection, before the initiation of any-study related interventions, but not cytotoxic therapy or darbopoetin- $\alpha$ administration. Two separate $8 \mathrm{ml}$ EDTA blood samples were obtained. Blood samples were centrifuged at $750 \mathrm{~g}$ for $10 \mathrm{~min}$ and plasma and serum were aliquoted and stored at $-80^{\circ} \mathrm{C}$. Analysis of all effector candidates was performed in one batch by investigators blinded to group allocation.

\section{Serum effector candidate analysis}

Inflammatory cytokine and angiogenic factors. A total of 34 cytokine and angiogenic factors (Supplementary Table S1) were assessed in pre- and post-intervention serum using multi-spot ELISA-based assays on the Meso Scale Discovery (MSD) Sector 
A
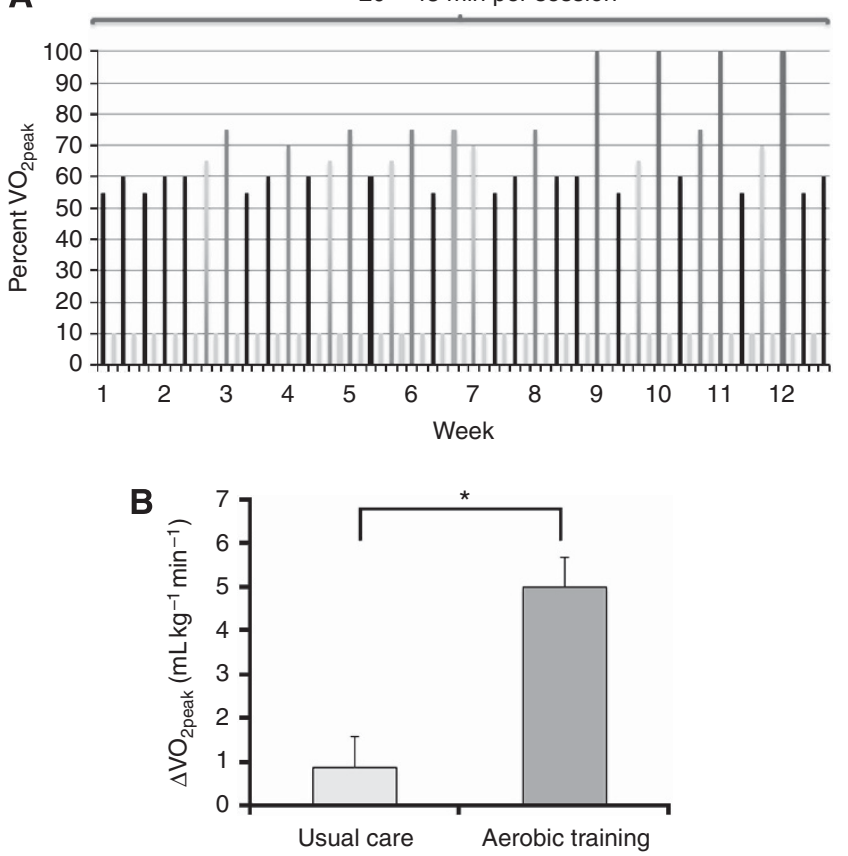

Group allocation

Figure 1. Aerobic training prescription and efficacy. (A) Nonlinear aerobic training prescription. Supervised aerobic training consisted of three supervised aerobic cycle ergometry sessions per week, 20-45 min per session, at $55 \%$ to $100 \%$ of peak oxygen consumption $\left(\mathrm{VO}_{2 \text { peak }}\right)$, on nonconsecutive days for 12 weeks. Aerobic training intensity was based on the workload $(\mathrm{W})$ corresponding to a specific percent of $\mathrm{VO}_{2 \text { peak }}$ (e.g., $55 \%, 65 \%$ ) elicited during the prerandomisation cardiopulmonary exercise test and was designed to improve $\mathrm{VO}_{2 \text { peak. }}$. Specifically, intensity is depicted by the coloured bars as a percentage of $\mathrm{VO}_{2 \text { peak: }}$ (1) black $55-60 \%$, (2) blue 65-70\%, (3) orange 70-80\%, and (4) red 100\%. Greycoloured bars represent rest (off) days. In weeks $1-4$, black and blue exercise sessions were $\sim 20-30$ min in duration; in weeks 5 to 8 , black and blue sessions were $\sim 30-45 \mathrm{~min}$ in duration, whereas orange sessions were for $\sim 20$ to $25 \mathrm{~min}$. In weeks 9 to 12 , black and blue sessions were $\sim 30-45 \mathrm{~min}$ in duration, orange sessions were $\geq 25 \mathrm{~min}$, whereas red sessions consisted of interval sessions for $30 \mathrm{~s}$ at $100 \% \mathrm{VO}_{2 \text { peak }}$ followed by 60 s of active recovery at $\sim 50 \% \mathrm{VO}_{2 \text { peak }}$ for 10-20 intervals. (B) Effect on $\mathrm{VO}_{2 \text { peak. }}$. Effect of aerobic training compared with usual care on delta change in mean absolute difference in $\mathrm{VO}_{2 \text { peak. }}$. Values are mean \pm s.d. ( $n=21-23$ per group). ${ }^{*} P<0.05$. A full colour version of this figure is available at the British Journal of Cancer journal online.

Imager 2400 (Meso Scale Discovery, Rockville, MD, USA) using either a 30-plex human cytokine bead-based assay (Invitrogen, Carlsbad, CA, USA) on a Bio-Plex 200 Luminex bead array reader (Bio-Rad, Hercules, CA, USA) or Quantkine colorimetric sandwich ELISA kits (R\&D Systems, Minneapolis, MN, USA). Briefly, assay beads were washed and added to pre-wetted 96-well plates. Incubation buffer was added to each well and $100 \mu \mathrm{l}$ of standard curve proteins or $100 \mu \mathrm{l}$ of diluted patient sample serum was added to appropriate wells. Plates were incubated for $2 \mathrm{~h}$ at room temperature on an orbital shaker and then washed. A $100 \mu$ l volume of biotinylated detector antibody was then added to each well, the plate reincubated for $1 \mathrm{~h}$ at room temperature on an orbital shaker, and then washed. A $100 \mu$ l volume of streptavidin-RPE was added to each well, then the plate was incubated for $30 \mathrm{~min}$ at room temperature on an orbital shaker, and then washed again. The plate was read on a Luminex Bio-Plex 100 liquid suspension array bead detector (Bio-Rad). All samples were run in duplicate and analyte concentrations derived using a five-parameter logistic model fit to the standard concentration curves.
Leukocyte phenotype (immune function). Fresh blood samples were centrifuged at $750 \mathrm{~g}$ for $10 \mathrm{~min}$ and the plasma fraction was removed and stored at $-80^{\circ} \mathrm{C}$. The buffy coat was removed, diluted with $1 \%$ BSA in PBS (Sigma-Aldrich Chemical Co., St Louis, MO, USA), layered on a Histopaque 1077 (Sigma-Aldrich) polysaccharide-sodium diatrizoate density gradient, and spun at $600 \mathrm{~g}$ for $30 \mathrm{~min}$. The cells at the gradient interface were removed, washed, and then counted using Trypan blue exclusion for use in flow cytometry. Flow cytometry studies were performed using the following mouse anti-human monoclonal antibodies (BD Pharmingen, Mississauga, ON, Canada): CD3-FITC, CD4-PE, CD8-PE, CD45RO-FITC, CD45RA-QR, CD62L-APC, CD14-APC, CD20FITC, CD16-PE, CD25-PE, and CD56-QR. Approximately $10^{6}$ cells were aliquoted into pretreated $\mathrm{V}$-well plates, incubated for $20 \mathrm{~min}$ in $2 \%$ human albumin to block Fc receptors, and then incubated for $30 \mathrm{~min}$ with antibodies, both steps occurring in the dark at $4{ }^{\circ} \mathrm{C}$. Cells were washed twice with FACS buffer ( $4 \%$ FBS in PBS), fixed in $1 \%$ paraformaldehyde, and stored at $4{ }^{\circ} \mathrm{C}$ until analysed on a FACScan flow cytometer (BD Biosciences, Sunnyvale, CA, USA). Gating was done on forward/side scatter plots to isolate the peripheral blood mononuclear cell (PBMC) fraction and $10^{4}$ cells were counted per patient. Matched isotype controls were used for each fluorochrome to determine thresholds for positive expression.

Metabolic profile. Seven conventional metabolites were assayed on a Beckman-Coulter DxC600 (Beckman-Coulter, Fullerton, CA, USA) clinical chemistry analyzer as previously described (Shah et al, 2012). Metabolic hormones were measured using ELISAs from MSD (Gaithersburg, MD, USA) for insulin and leptin; and Beckman for insulin-like growth factor. Levels of 15 amino acids and 45 acylcarnitines were quantified using targeted mass spectrometry-based approaches, as reported previously (Shah et al, 2012). For analysis, we used tandem mass spectrometry with a Quattro Micro instrument (Waters Corp., Milford, MA, USA). A nontargeted gas chromatography-mass spectrometry method was used to detect and quantify other metabolites not assessed via targeted approaches, as described previously (McNulty et al, 2011).

Statistical analysis. In general, the data were not normally distributed and thus Wilcoxon rank-sum tests were used to compare differences in the central tendencies of the change from pre to post for each blood effector candidate between groups. As this analysis was exploratory, no adjustments to $P$-values were made for multiple comparisons. Hierarchical clustering was used to display the correlation among the metabolomics profiles from all processed samples, and from the differences calculated for pre and post pairs. All analyses were conducted under the intention-totreat (ITT) principle. The ITT analysis included all participants in their randomly assigned group, regardless of adherence to the intervention. False discovery rate (FDR)-adjusted $P$-values were estimated using the Benjamini and Hochberg (BH) method. A twosided significance level of 0.05 was used for all statistical tests. All statistical analyses were conducted using SAS version 9.2 (SAS Institute, Cary, NC, USA).

\section{RESULTS}

Baseline characteristics of the experimental groups were well balanced (Table 1). Overall adherence to aerobic training treatment was $84 \%$; the between-group delta change in cardiopulmonary function (i.e., $\mathrm{VO}_{2 \text { peak }}$ ) was $+4.1 \mathrm{ml} \mathrm{kg}^{-1} \min ^{-1}$, favouring aerobic training $(P<0.05$; Figure $1 \mathrm{~B})$, demonstrating that patients were exposed to a physiologically effective dose of aerobic training (Courneya et al, 2008). Thus, this trial provided an appropriate 
context in which to conduct a correlative science study exploring the effects of aerobic training on the host systemic milieu.

Effects on cytokine and angiogenic factors. Changes in select cytokines and angiogenic factors are presented in Table 2 (and Supplementary Table S1). Significant pre-post between-group

\section{Table 1. Characteristics of the participants}

\begin{tabular}{|c|c|c|}
\hline Variable & $\begin{array}{c}\text { Usual care } \\
(n=21)\end{array}$ & $\begin{array}{l}\text { Aerobic training } \\
(n=23)\end{array}$ \\
\hline Age & $54(11)$ & $56(10)$ \\
\hline Female, no. (\%) & $18(86)$ & $18(78)$ \\
\hline Weight, kg & $69.7(11.4)$ & $70.1(11.0)$ \\
\hline BMI, $\mathrm{kg} \mathrm{m}^{-2}$ (s.d.) & $26.0(4.7)$ & $26.0(3.7)$ \\
\hline ECOG 0-1, no. (\%) & $20(95)$ & $22(96)$ \\
\hline \multicolumn{3}{|l|}{ Primary diagnosis, no. (\%) } \\
\hline $\begin{array}{l}\text { Breast } \\
\text { Lung } \\
\text { Bladder } \\
\text { Abdomen } \\
\text { Peritoneal } \\
\text { Primary unknown } \\
\text { Rectum } \\
\text { Uterus } \\
\text { Nasopharynx }\end{array}$ & $\begin{array}{l}11(52) \\
4(19) \\
1(5) \\
1(5) \\
1(5) \\
1(5) \\
1(5) \\
1(5) \\
-\end{array}$ & $\begin{array}{l}13(56) \\
1(4) \\
- \\
1(4) \\
2(8) \\
- \\
3(13) \\
1(4) \\
2(8)\end{array}$ \\
\hline \multicolumn{3}{|l|}{ Disease stage } \\
\hline $\begin{array}{l}\text { Metastatic disease, no. (\%) } \\
\text { Current chemotherapy, no. (\%) } \\
\text { Current radiation, no. (\%) } \\
\text { Haemoglobin level, g dl }\end{array}$ & $\begin{aligned} & 8(38) \\
& 19(90) \\
& 2(10) \\
& 9.9(0.7)\end{aligned}$ & $\begin{aligned} 14 & (60) \\
22 & (96) \\
4 & (17) \\
10.4 & (0.6)\end{aligned}$ \\
\hline \multicolumn{3}{|l|}{ Cardiopulmonary function data } \\
\hline $\begin{array}{l}\mathrm{VO}_{2 \text { peak, }} \mathrm{ml} \mathrm{kg}^{-1} \mathrm{~min}^{-1} \\
\text { Percent below age-sex normative } \\
\mathrm{VO}_{2 \text { peak }} \\
\mathrm{VO}_{\text {2peak, I I in }}{ }^{-1} \\
\text { Peak workload, watts }\end{array}$ & $\begin{array}{l}16.2(4.3) \\
39 \%(13) \\
1.10(0.27) \\
81.9(29.6)\end{array}$ & $\begin{array}{l}15.5(3.7) \\
40 \%(14) \\
1.07(0.27) \\
82.4(24.3)\end{array}$ \\
\hline \multicolumn{3}{|c|}{ Concomitant comorbidities, no. (\%) } \\
\hline Cardiac disease & $4(19)$ & $5(22)$ \\
\hline
\end{tabular}

differences for five cytokine and angiogenic factors (HGF, IL-4, macrophage inflammatory protein-1 $\beta$ (MIP-1 $\beta$ ), vascular endothelial growth factor (VEGF), and TNF- $\alpha$ ) favour the aerobic training group (unadjusted $P$ 's $<0.05$; Table 2 and Supplementary Table S1). Specifically, HGF decreased by $74 \mathrm{pg} \mathrm{ml}^{-1}(-24 \%)$ in the aerobic training group and increased by $69 \mathrm{pg} \mathrm{ml}^{-1}(+30 \%)$ in the usual care group $(P=0.008)$; IL-4 decreased by $4 \mathrm{pg} \mathrm{ml}^{-1}(-3.5 \%)$ in the aerobic training group and increased by $3 \mathrm{pg} \mathrm{ml}^{-1}(+2.6 \%)$ in the usual care group $(P=0.012)$; MIP-1 $\beta$ decreased by $14 \mathrm{pg} \mathrm{ml}^{-1}(-7.9 \%)$ in the aerobic training group and increased by $7 \mathrm{pg} \mathrm{ml}^{-1}(+4.6 \%)$ in the usual care group $(P=0.034)$; VEGF decreased by $3 \mathrm{pg} \mathrm{ml}^{-1}$ $(-23 \%)$ in the aerobic training group and increased by $2 \mathrm{pg} \mathrm{ml}^{-1}(+1.2 \%)$ in the usual care group $(P=0.043)$; and TNF- $\alpha$ concentration did not change $(0 \%)$ in the aerobic training group and increased by $1 \mathrm{pg} \mathrm{ml}^{-1}(+50 \%)$ in the usual care group $(P=0.046)$.

Effects on leukocyte phenotype. Changes in leukocyte phenotypes are presented in Table 3. Analyses indicated nonsignificant pre-post between-group differences for $\mathrm{T}$ lymphocytes $\mathrm{CD} 4{ }^{+}$, $\mathrm{CD} 8{ }^{+}$, and $\mathrm{CD} 8{ }^{+} / \mathrm{CD} 45 \mathrm{RA}(P<0.10$; Table 3$)$. For these factors, circulating concentrations generally increased from baseline to week 12 in the aerobic training group compared with decreases or no change in the usual care group. No significant changes were observed for B lymphocytes, NK cells, or monocyte phenotypes (Table 3).

Effects on conventional and novel metabolic hormones. Analyses of conventional metabolites including triglycerides, ketones, nonesterified fatty acids, 3-hydroxybutyrate, and phosphate indicated nonsignificant pre-post group differences (Supplementary Table S2). Common metabolic hormones including glucose, IGF-1, insulin, lactate, and leptin also indicated nonsignificant pre-post group differences (Supplementary Table S2). Targeted mass spectrometry of 15 amino acids and 45 acylcarnities was unchanged between groups (Supplementary Tables S3 and S4). In addition, nontargeted mass spectrometry of 55 metabolites indicated nonsignificant changes between usual care and aerobic training (Supplementary Table S5).

Table 2. Effects on peripheral blood cytokines and angiogenic factors

\begin{tabular}{|c|c|c|c|c|c|}
\hline & \multicolumn{2}{|c|}{ Baseline } & \multicolumn{2}{|c|}{ Month 3} & \multirow[b]{2}{*}{$P$-value } \\
\hline Cytokine and angiogenic factor treatment group & Median (pg ml ${ }^{-1}$ ) & IQR $\left(\mathrm{pg} \mathrm{ml}^{-1}\right)$ & Median (pg ml ${ }^{-1}$ ) & IQR $\left(\mathrm{pg} \mathrm{ml} \mathrm{I}^{-1}\right)$ & \\
\hline \multicolumn{6}{|l|}{ Hepatocyte growth factor (HGF) } \\
\hline Usual care & 226 & $132-354$ & 295 & $218-503$ & \\
\hline Aerobic training & 310 & $209-499$ & 236 & $130-426$ & 0.008 \\
\hline \multicolumn{6}{|l|}{ Interleukin-4 (IL-4) } \\
\hline Usual care & 117 & $77-122$ & 120 & $79-138$ & \\
\hline Aerobic training & 115 & $77-120$ & 111 & $74-120$ & 0.012 \\
\hline \multicolumn{6}{|l|}{ MIP-1 $\beta /$ CCL4 } \\
\hline Usual care & 152 & $125-199$ & 159 & $136-217$ & \\
\hline Aerobic training & 177 & $123-265$ & 163 & $114-205$ & 0.034 \\
\hline \multicolumn{6}{|l|}{ Vascular endothelial growth factor (VEGF) } \\
\hline Usual care & 9 & $1-18$ & 11 & $3-16$ & \\
\hline Aerobic training & 13 & $3-22$ & 10 & $1-20$ & 0.043 \\
\hline \multicolumn{6}{|l|}{ Tumour necrosis factor- $\alpha$ (TNF- $\alpha$ ) } \\
\hline Usual care & 2 & $1-3$ & 3 & $1-5$ & \\
\hline Aerobic training & 1 & $1-3$ & 1 & $1-3$ & 0.046 \\
\hline
\end{tabular}


Table 3. Effects on peripheral blood leukocyte phenotype

\begin{tabular}{|c|c|c|c|c|c|}
\hline Cell type and group & Baseline & Month 3 & $\begin{array}{c}\text { Absolute } \\
\text { mean change }\end{array}$ & $\begin{array}{l}\text { Between-group } \\
\text { mean difference }\end{array}$ & $P$-value ${ }^{\text {a }}$ \\
\hline \multicolumn{6}{|l|}{ Cytotoxic T lymphocytes } \\
\hline $\begin{array}{l}\text { CD4 } 4^{+}(\mathrm{T} \text { helper }(\mathrm{Th}) \text { cells }) \\
\text { Usual care } \\
\text { Aerobic training }\end{array}$ & $\begin{array}{l}22.2 \%(7.5)^{b} \\
23.6 \%(7.9)\end{array}$ & $\begin{array}{l}19.0 \%(9.4) \\
24.4 \%(7.7)\end{array}$ & $\begin{array}{l}-3.2 \% \\
+0.8 \%\end{array}$ & $-4.0 \%$ & 0.063 \\
\hline $\begin{array}{l}\mathrm{CD}^{+} / \mathrm{CD} 25^{+} \text {(activated Th cells) } \\
\text { Usual care } \\
\text { Aerobic training }\end{array}$ & $\begin{array}{l}2.8 \%(2.1) \\
3.7 \%(3.4)\end{array}$ & $\begin{array}{l}5.0 \%(7.0) \\
3.6 \%(6.0)\end{array}$ & $\begin{array}{l}+2.2 \% \\
-0.1 \%\end{array}$ & $2.3 \%$ & 0.315 \\
\hline $\begin{array}{l}\text { CD4 }{ }^{+} / \text {CD } 45 R A \text { (naive Th cells) } \\
\text { Usual care } \\
\text { Aerobic training }\end{array}$ & $\begin{array}{l}21.9 \%(14.6) \\
19.2 \%(10.3)\end{array}$ & $\begin{array}{l}18.3 \%(15.5) \\
16.8 \%(9.6)\end{array}$ & $\begin{array}{l}-3.6 \% \\
-2.4 \%\end{array}$ & $-1.2 \%$ & 0.890 \\
\hline $\begin{array}{l}\text { CD4 }{ }^{+} \text {/ CD45RO (memory Th cells) } \\
\text { Usual care } \\
\text { Aerobic training }\end{array}$ & $\begin{array}{l}30.1 \%(7.6) \\
30.3 \%(10.2)\end{array}$ & $\begin{array}{l}31.3 \%(9.3) \\
33.8 \%(10.2)\end{array}$ & $\begin{array}{l}+1.2 \% \\
+3.5 \%\end{array}$ & $-2.3 \%$ & 0.269 \\
\hline $\begin{array}{l}\mathrm{CD}^{+} / \mathrm{CD}^{+} 2 \mathrm{~L}^{+} \text {(central memory Th cells) } \\
\text { Usual care } \\
\text { Aerobic training }\end{array}$ & $\begin{array}{l}26.5 \%(11.4) \\
26.1 \%(13.1)\end{array}$ & $\begin{array}{l}25.6 \%(10.1) \\
26.5 \%(12.4)\end{array}$ & $\begin{array}{l}-0.9 \% \\
+0.4 \% \\
\end{array}$ & $-1.3 \%$ & 0.851 \\
\hline $\begin{array}{l}\mathrm{CD}^{+} \text {(cytotoxic T cells) } \\
\text { Usual care } \\
\text { Aerobic training }\end{array}$ & $\begin{array}{l}48.8 \%(11.1) \\
42.9 \%(14.4)\end{array}$ & $\begin{array}{l}42.6 \%(12.6) \\
46.7 \%(13.8)\end{array}$ & $\begin{array}{l}-6.2 \% \\
+3.8 \%\end{array}$ & $-10 \%$ & 0.101 \\
\hline $\begin{array}{l}\text { CD8 }{ }^{+} / \text {CD } 45 R A \text { (naive cytotoxic } T \text { cells) } \\
\text { Usual care } \\
\text { Aerobic training }\end{array}$ & $\begin{array}{l}16.3 \%(7.1) \\
13.5 \%(6.3)\end{array}$ & $\begin{array}{l}11.6 \%(5.0) \\
15.8 \%(6.0)\end{array}$ & $\begin{array}{l}-4.7 \% \\
+2.3 \%\end{array}$ & $-7 \%$ & 0.081 \\
\hline $\begin{array}{l}\text { CD8 }{ }^{+} / \mathrm{CD} 45 \mathrm{RO} \text { (memory cytotoxic T cells) } \\
\text { Usual care } \\
\text { Aerobic training }\end{array}$ & $\begin{array}{l}9.1 \%(6.2) \\
7.0 \%(4.8)\end{array}$ & $\begin{array}{l}11.0 \%(5.7) \\
11.1 \%(7.2)\end{array}$ & $\begin{array}{l}+1.9 \% \\
+4.1 \%\end{array}$ & $-2.2 \%$ & 0.755 \\
\hline $\begin{array}{l}\mathrm{CD}^{+} / \mathrm{CD} 25^{+} \text {(activated cytotoxic } \mathrm{T} \text { cells) } \\
\text { Usual care } \\
\text { Aerobic training }\end{array}$ & $\begin{array}{l}3.4 \%(3.2) \\
4.7 \%(3.0)\end{array}$ & $\begin{array}{l}5.5 \%(2.8) \\
5.8 \%(7.4)\end{array}$ & $\begin{array}{l}+2.1 \% \\
+1.1 \%\end{array}$ & $1 \%$ & 0.337 \\
\hline \multicolumn{6}{|l|}{ B lymphocytes } \\
\hline $\begin{array}{l}\mathrm{CD} 20^{+}(\mathrm{B} \text { cells }) \\
\text { Usual care } \\
\text { Aerobic training }\end{array}$ & $\begin{array}{l}41.0 \%(12.4) \\
41.8 \%(16.9)\end{array}$ & $\begin{array}{l}46.5 \%(15.1) \\
43.0 \%(11.6)\end{array}$ & $\begin{array}{l}+5.5 \% \\
+1.2 \%\end{array}$ & $4.3 \%$ & 0.852 \\
\hline $\begin{array}{l}\mathrm{CD} 20^{+} / \mathrm{CD} 54^{+} \text {(activated B cells) } \\
\text { Usual care } \\
\text { Aerobic training }\end{array}$ & $\begin{array}{l}4.1 \%(1.4) \\
7.1 \%(6.5)\end{array}$ & $\begin{array}{l}5.9 \%(2.9) \\
7.7 \%(4.5)\end{array}$ & $\begin{array}{l}+1.8 \% \\
+0.6 \%\end{array}$ & $1.2 \%$ & 0.787 \\
\hline \multicolumn{6}{|l|}{ Natural killer (NK) cells } \\
\hline $\begin{array}{l}\mathrm{CD}^{+} / \mathrm{CD}^{\circ} 6^{+} \text {(NKT cells) } \\
\text { Usual care } \\
\text { Aerobic training }\end{array}$ & $\begin{array}{l}5.1 \%(3.5) \\
6.2 \%(5.0)\end{array}$ & $\begin{array}{l}4.3 \%(2.9) \\
5.7 \%(4.1)\end{array}$ & $\begin{array}{l}-0.8 \% \\
-0.5 \%\end{array}$ & $-0.3 \%$ & 0.512 \\
\hline $\begin{array}{l}\mathrm{CD} 16^{+} / \mathrm{CD}^{+} 6^{+} \text {(NK cells) } \\
\text { Usual care } \\
\text { Aerobic training }\end{array}$ & $\begin{array}{l}8.8 \%(5.5) \\
8.2 \%(4.4)\end{array}$ & $\begin{array}{l}9.8 \%(8.0) \\
9.7 \%(8.4)\end{array}$ & $\begin{array}{l}+1.0 \% \\
+1.5 \%\end{array}$ & $-0.5 \%$ & 0.929 \\
\hline \multicolumn{6}{|l|}{ Monocytes } \\
\hline $\begin{array}{l}\text { CD14 }{ }^{+} / \text {CD } 54^{+} \text {(activated monocytes) } \\
\text { Usual care } \\
\text { Aerobic training }\end{array}$ & $\begin{array}{l}8.4 \%(5.9) \\
7.9 \%(7.8)\end{array}$ & $\begin{array}{l}13.2 \%(10.5) \\
11.8 \%(8.8)\end{array}$ & $\begin{array}{l}+4.8 \% \\
+3.9 \%\end{array}$ & $0.9 \%$ & 0.949 \\
\hline
\end{tabular}

\section{DISCUSSION}

Compared with usual care, chronic aerobic training significantly decreased systemic bioavailability of select cytokine and angiogenic factors that occurred in conjunction with nonsignificant changes in the number of select $\mathrm{T}$ lymphocytes in patients with solid tumours undergoing cytotoxic and synthetic erythropoietin therapy. Interestingly, the most robust changes were observed in pro-inflammatory cytokine and angiogenic factors; in general, aerobic training decreased concentrations of several cytokine and angiogenic factors, including significant decreases in HGF, IL-4, MIP-1 $\beta$, VEGF, and TNF- $\alpha$, compared with usual care.
Nevertheless, it is important to state that our data are exploratory/ hypothesis generating and by no means definitive.

The limited studies to date investigating the effects of exercise training on cytokine and angiogenic factors have yielded divergent findings. For example, Jones et al (2013b) found no changes in C-reactive protein, IL-6, and TNF- $\alpha$ in early breast cancer patients following 6 months of aerobic exercise. Fairey et al (2005) also found no changes in several pro-inflammatory cytokines following 15 weeks of supervised moderate-intensity aerobic training in breast cancer patients after completion of primary adjuvant therapy. In prior work by our group, we found that supervised moderate- to high-intensity aerobic training significantly decreased plasma concentrations of placenta growth factor, IL-1 $\beta$, and IL-2 
in early breast cancer patients receiving conventional chemotherapy, relative to chemotherapy alone (Jones et al, 2013a).

Complex cross-talk exists between antitumour immunity and inflammation in malignant states (Lin and Karin, 2007). A proinflammatory systemic milieu promotes multiple direct and indirect immunosuppressive processes including suppression of effector T-cell penetration and activation (in tumour beds; Mellman et al, 2011). Thus, aerobic training may improve immune activation through suppression of inflammatory cytokine and angiogenic factors during cytotoxic therapy. In support of this notion, in the present exploratory study, aerobic training induced reductions in select cytokine and angiogenic factors that occurred in conjunction with a shift towards improvements, although nonsignificant, in the number of activated $\mathrm{T}$ lymphocytes. This may be important as $\mathrm{T}$ lymphocytes express death receptor ligands that trigger apoptotic machinery via death receptor binding (Cappello et al, 2002). Further work investigating the impact of aerobic training on the dynamic interplay between immunity and inflammation in malignant states is warranted. Although our study represents the most comprehensive evaluation of the effects of exercise on circulating metabolic hormones, including the first to exploit metabolomics, we observed no changes in any metabolic intermediate; this is in contrast to well-characterised effects of aerobic training to improve (normalise) metabolic abnormalities in noncancer clinical populations (Umpierre et al, 2011). Our null findings may reflect the relatively normal patient baseline metabolic profile (mean BMI $26 \mathrm{~kg} \mathrm{~m}^{-2}$ ), the rapid clearance of circulating metabolic intermediates following an acute bout of aerobic training, or the masking effects of cytotoxic and/or synthetic erythropoietin therapy on aerobic training modulation of metabolic intermediates (Lewis et al, 2010).

In addition, patients in our study were receiving cytotoxic therapy and darbopoetin- $\alpha$ that may have contaminated the effects of aerobic training-conditioned sera through perturbations in inflammatory cytokine response despite all chemotherapeutic agents being undetectable in peripheral blood within $1-2 \mathrm{~h}$ of infusion. Although exposure of in vitro or in vivo models of breast cancer to erythropoietin causes minimal alterations in phenotype, the addition of synthetic erythropoietin with aerobic training may affect additional systemic factors not measured in this study (LaMontagne et al, 2006). As such, caution is required when interpreting our findings, given the heterogeneous nature of our study sample, the fact that type and timing of cytotoxic therapy was not controlled between groups, and the small sample size.

On the current evidence base it is difficult to draw clear conclusions regarding the efficacy of aerobic training as an effective strategy to modify a proinflammatory (tumourigenic) host milieu. The inconsistent nature of available evidence is not, however, surprising given the large interpatient basal variation in systemic effector profile and the highly variable and adaptive systemic response to aerobic training. In addition, comparisons between studies are difficult given the inclusion of patients with different tumour types, prior or concurrent cytotoxic/supportive care therapy, and differences in the aerobic training prescription (i.e., intensity, length, frequency, and duration of training). Conduct of exercise-oncology trials with assessment of a homogenous panel of candidate correlative biomarkers, in homogeneous cohorts, will permit identification of peripheral blood-based biomarkers altered by aerobic training. In the long term, these efforts will lead to predictive biomarkers correlating with aerobic training response that in turn will enable selection of patients most likely to benefit from this treatment, as well as improve the development of more effective aerobic training prescriptions or combinational approaches to optimally alter peripheral blood-based biomarkers.

In conclusion, our exploratory findings suggest that supervised aerobic training may be one strategy to modulate select systemic immune-inflammatory candidate effectors in patients with solid tumours undergoing cytotoxic and synthetic erythropoietin therapy. If confirmed, modulation of these effectors could have implications for cancer progression, recurrence, and/or response to therapy.

\section{ACKNOWLEDGEMENTS}

This study was supported by funds from George and Susan Beischer (LWJ). KS Courneya is supported by the Canada Research Chairs Program. LW Jones is supported by grants from the National Cancer Institute.

\section{CONFLICT OF INTEREST}

The authors declare no conflict of interest.

\section{REFERENCES}

Ballard-Barbash R, Friedenreich CM, Courneya KS, Siddiqi SM, Mctiernan A, Alfano CM (2012) Physical activity, biomarkers, and disease outcomes in cancer survivors: a systematic review. J Natl Cancer Inst 104: 815-840.

Barcellos-Hoff MH, Lyden D, Wang TC (2013) The evolution of the cancer niche during multistage carcinogenesis. Nat Rev Cancer 13: 511-518.

Betof AS, Dewhirst MW, Jones LW (2013) Effects and potential mechanisms of exercise training on cancer progression: a translational perspective. Brain Behav Immun 30(Suppl): S75-S87.

Cappello P, Novelli F, Forni G, Giovarelli M (2002) Death receptor ligands in tumors. J Immunother 25: 1-15.

Courneya KS, Jones LW, Peddle CJ, Sellar CM, Reiman T, Joy AA, Chua N, Tkachuk L, Mackey JR (2008) Effects of aerobic exercise training in anemic cancer patients receiving darbepoetin alfa: a randomized controlled trial. Oncologist 13: 1012-1020.

Fairey AS, Courneya KS, Field CJ, Bell GJ, Jones LW, Mackey JR (2005) Randomized controlled trial of exercise and blood immune function in postmenopausal breast cancer survivors. J Appl Physiol (1985), 98 $1534-1540$.

Goodwin PJ, Ennis M, Pritchard KI, Trudeau ME, Koo J, Taylor SK, Hood N (2012) Insulin- and obesity-related variables in early-stage breast cancer: correlations and time course of prognostic associations. J Clin Oncol 30: 164-171.

Hursting SD, Berger NA (2010) Energy balance, host-related factors, and cancer progression. J Clin Oncol 28: 4058-4065.

Jones LW, Alfano CM (2013) Exercise-oncology research: past, present, and future. Acta Oncol 52: 195-215.

Jones LW, Fels DR, West M, Broadwater G, Barry WT, Wilke LG, Masko EM, Douglas P, Dash R, Povsic T, Peppercorn J, Marcom K, Blackwell K, Kimmick G, Dewhirst MW (2013a) Modulation of circulating angiogenic factors and tumor biology by aerobic training in breast cancer patients receiving neoadjuvant chemotherapy. Cancer Prev Res (Phila) 6: 925-937.

Jones LW, Liang Y, Pituskin EN, Battaglini CL, Scott JM, Hornsby WE, Haykowsky M (2011) Effect of exercise training on peak oxygen consumption in patients with cancer: a meta-analysis. Oncologist 16: $112-120$.

Jones SB, Thomas GA, Hesselsweet SD, Alvarez-Reeves M, Yu H, Irwin ML (2013b) Effect of exercise on markers of inflammation in breast cancer survivors: the Yale exercise and survivorship study. Cancer Prev Res (Phila) 6: 109-118.

Joyner MJ, Green DJ (2009) Exercise protects the cardiovascular system: effects beyond traditional risk factors. J Physiol 587: 5551-5558.

Kodama S, Saito K, Tanaka S, Maki M, Yachi Y, Asumi M, Sugawara A, Totsuka K, Shimano H, Ohashi Y, Yamada N, Sone H (2009) Cardiorespiratory fitness as a quantitative predictor of all-cause mortality and cardiovascular events in healthy men and women: a meta-analysis. JAMA 301: 2024-2035.

LaMontagne KR, Butler J, Marshall DJ, Tullai J, Gechtman Z, Hall C, Meshaw A, Farrell FX (2006) Recombinant epoetins do not stimulate tumor growth in erythropoietin receptor-positive breast carcinoma models. Mol Cancer Ther 5: 347-355. 
Lee IM, Shiroma EJ, Lobelo F, Puska P, Blair SN, Katzmarzyk PT. Lancet Physical Activity Series Working Group (2012) Effect of physical inactivity on major non-communicable diseases worldwide: an analysis of burden of disease and life expectancy. Lancet 380: 219-229.

Lewis GD, Farrell L, Wood MJ, Martinovic M, Arany Z, Rowe GC, Souza A, Cheng S, Mccabe EL, Yang E, Shi X, Deo R, Roth FP, Asnani A, Rhee EP, Systrom DM, Semigran MJ, Vasan RS, Carr SA, Wang TJ, Sabatine MS, Clish CB, Gerszten RE (2010) Metabolic signatures of exercise in human plasma. Sci Transl Med 2: 33ra37.

Lin WW, Karin M (2007) A cytokine-mediated link between innate immunity, inflammation, and cancer. J Clin Invest 117: 1175-1183.

McAllister SS, Gifford AM, Greiner AL, Kelleher SP, Saelzler MP, Ince TA, Reinhardt F, Harris LN, Hylander BL, Repasky EA, Weinberg RA (2008) Systemic endocrine instigation of indolent tumor growth requires osteopontin. Cell 133: 994-1005.

McAllister SS, Weinberg RA (2010) Tumor-host interactions: a far-reaching relationship. J Clin Oncol 28: 4022-4028.

McNulty NP, Yatsunenko T, Hsiao A, Faith JJ, Muegge BD, Goodman AL, Henrissat B, Oozeer R, Cools-Portier S, Gobert G, Chervaux C, Knights D, Lozupone CA, Knight R, Duncan AE, Bain JR, Muehlbauer MJ, Newgard CB, Heath AC, Gordon JI (2011) The impact of a consortium of fermented milk strains on the gut microbiome of gnotobiotic mice and monozygotic twins. Sci Transl Med 3: 106ra106.

Mellman I, Coukos G, Dranoff G (2011) Cancer immunotherapy comes of age. Nature 480: 480-489.

Shah SH, Sun JL, Stevens RD, Bain JR, Muehlbauer MJ, Pieper KS, Haynes C, Hauser ER, Kraus WE, Granger CB, Newgard CB, Califf RM, Newby LK (2012) Baseline metabolomic profiles predict cardiovascular events in patients at risk for coronary artery disease. Am Heart J 163: 844-850 el.
Sheen-Chen SM, Chen WJ, Eng HL, Chou FF (1997) Serum concentration of tumor necrosis factor in patients with breast cancer. Breast Cancer Res Treat 43: 211-215.

Sheen-Chen SM, Liu YW, Eng HL, Chou FF (2005) Serum levels of hepatocyte growth factor in patients with breast cancer. Cancer Epidemiol Biomarkers Prev 14: 715-717.

Speck RM, Courneya KS, Masse LC, Duval S, Schmitz KH (2010) An update of controlled physical activity trials in cancer survivors: a systematic review and meta-analysis. J Cancer Surviv 4: 87-100.

Straussman R, Morikawa T, Shee K, Barzily-Rokni M, Qian ZR, Du J, Davis A, Mongare MM, Gould J, Frederick DT, Cooper ZA, Chapman PB, Solit DB, Ribas A, Lo RS, Flaherty KT, Ogino S, Wargo JA, Golub TR (2012) Tumour micro-environment elicits innate resistance to RAF inhibitors through HGF secretion. Nature 487: 500-504.

Umpierre D, Ribeiro PA, Kramer CK, Leitao CB, Zucatti AT, Azevedo MJ, Gross JL, Ribeiro JP, Schaan BD (2011) Physical activity advice only or structured exercise training and association with HbAlc levels in type 2 diabetes: a systematic review and meta-analysis. JAMA 305: 1790-1799.

Zhang GJ, Adachi I (1999) Serum interleukin-6 levels correlate to tumor progression and prognosis in metastatic breast carcinoma. Anticancer Res 19: 1427-1432.

This work is published under the standard license to publish agreement. After 12 months the work will become freely available and the license terms will switch to a Creative Commons AttributionNonCommercial-Share Alike 4.0 Unported License.

Supplementary Information accompanies this paper on British Journal of Cancer website (http://www.nature.com/bjc) 